\title{
Accessory deciduomata in artificially prolonged pseudopregnancy in the golden hamster
}

\author{
R. Pijnenborg*, I. Brosens and W. B. Robertson $\dagger$ \\ Laboratory for Gynaecological Physiopathology, University of Leuven, Belgium
}

In the golden hamster (Mesocricetus auratus) pseudopregnancy lasts for only 9 or 10 days. If deciduomata are induced during pseudopregnancy they undergo necrosis from Day 8 onwards (Turnbull \& Kent, 1963), but if deciduomata are induced in a sterile horn, they are maintained throughout the whole 16 days of the pregnancy (Orsini, 1968). We have shown in an earlier study of hamster pregnancy (Pijnenborg, Robertson \& Brosens, 1974) that the spiral arteries of the placental bed and of deciduomata undergo progressive decidualization. The morphological changes can be timed precisely according to the day of gestation; spontaneous necrosis of the decidualized spiral arteries of deciduomata begins on Day 12 and extends to the myometrial segments, but even by term does not involve the medial terminal arteries. At about the time that necrosis begins in the spiral arteries of deciduomata there is a sharp fall in the peripheral plasma progesterone level (Lukaszewska \& Greenwald, 1970; Gutknecht, Wyngarden \& Pharriss, 1971). It seemed possible that the necrosis could be due to progesterone deprivation, but experiments to test this hypothesis (Pijnenborg et al., 1975) failed to prevent spiral artery necrosis even when the peripheral plasma progesterone level was kept artificially high by daily parenteral injections of progesterone. To investigate the matter further we have compared the deciduomata induced in hamsters in which pseudopregnancy was artificially prolonged and fetal tissue was absent with the deciduomata induced in the sterile horn of unilaterally pregnant hamsters as described earlier (Pijnenborg et al., 1974).

Pseudopregnancy was induced in 7 virgin hamsters by mating with a vasectomized male. The morning after the sterile copulation was designated Day 1 of pseudopregnancy. At laparotomy on Day 4 a piece of thread was inserted into each uterine horn and at Day 7 both ovaries were removed. Daily s.c. injections of $5 \mathrm{mg}$ progesterone in arachis oil were given from Day 6 until the animals were killed-3 at Day 15, 2 at Day 18 and 2 at Day 20. One further animal was killed at Day 9 of pseudopregnancy and another at Day 10. All deciduomata, identified by careful inspection of the uteri, were dissected out with the related segments of uteri, fixed in Bouin's solution and embedded in paraffin wax. Sections from each block were stained with haemalum and eosin.

The results are shown in Table 1. Although the time sequence of events in deciduomata in the intact pseudopregnant hamster may not be exactly the same as in deciduomata in a unilaterally pregnant hamster, the histological criteria for dating were applied as for the latter.

Table 1. The biological age of deciduomata from golden hamsters in which pseudopregnancy was prolonged

\begin{tabular}{cccc}
\hline \multirow{2}{*}{$\begin{array}{c}\text { Day of prolonged } \\
\text { pseudopregnancy }\end{array}$} & $\begin{array}{c}\text { No. of } \\
\text { animals }\end{array}$ & No. & \multicolumn{2}{c}{ Age } \\
\cline { 4 - 4 } 15 & 3 & 4 & Day 15 \\
& & 4 & Days 7-8 \\
18 & 2 & 5 & Day 18 \\
& & 2 & Day 10 \\
& & 1 & Days 7-8 \\
20 & 2 & 5 & Day 20 \\
& & 1 & Day 12 \\
& & 1 & Day 10 \\
& & 5 & Days 7-8
\end{tabular}

* Present address: Department of Obstetrics, Bristol Maternity Hospital, Bristol BS2 8EG, U.K.

+ Present address: St. George's Hospital Medical School, London, U.K. 
An unexpected and interesting finding was that two separate sets of deciduomata could be distinguished histologically, one having the expected biological ages (Days 15, 18 and 20) and the other being much younger (Days 7-10). The necrotic spiral arteries of a Day 18 deciduoma are illustrated in Pl. 1, Fig. 1, while Pl. 1, Fig. 2 shows the decidualized spiral arteries at Day 7 or 8 of a deciduoma from the same animal.

The mechanism underlying the formation of accessory deciduomata in the pseudopregnant hamster is conjectural. It is unlikely that they represent a growth-retarded cohort of those induced at Day 4 because at the second laparotomy for ovariectomy on Day 7 the sites of all developing deciduomata were carefully noted and the accessory deciduomata found at autopsy were in new sites. Moreover, all the deciduomata taken from pseudopregnant animals at Days 9 and 10 showed a histological structure corresponding with their chronological age.

It is probable that deciduoma formation in the hamster requires a 'pro-oestrous' oestrogen priming of the endometrium, as in the mouse (Finn \& Pollard, 1973). The ovaries removed from the hamsters at Day 7 showed follicular growth with antrum formation which may have produced sufficient oestrogen to allow a second set of deciduomata to be initiated by the presence of the irritant thread and to develop under the influence of the exogenous progesterone.

The accessory deciduomata do not seem to achieve the same degree of development as the initial ones. At autopsy most accessory deciduomata were still in the immature stage (Days 7-8), and only two had achieved the Day 10 stage by Day 18. One deciduoma at Day 20 was classified as having a Day 12 biological age and it showed necrosis in the distal tips of the central spiral arteries. From our small series it cannot be concluded whether there really is a slowing down of the developmental rate, due perhaps to suboptimal oestrogen priming, or whether there is a continuous production of new accessory deciduomata.

The deciduomata at Days 18 and 20 of development presented an exaggerated picture of what is seen in a deciduoma in the sterile horn of a unilaterally pregnant hamster at term (Day 16). At Day 18 (P1. 1, Fig. 1) the degree of necrosis in the spiral arteries was greater than that seen at term, and by Day 20 (Pl. 1, Fig. 3) the whole decidua was so necrotic that it was difficult to identify any discrete structure in these vessels. In deciduomata associated with normal pregnancy the medial terminal arteries, i.e. those in the mesometrial triangle that give rise to the central spiral arteries, are completely decidualized at term but do not undergo the necrosis that affects the decidual spiral arteries (Pijnenborg et al., 1974). However, in the deciduomata of pseudopregnancy necrosis of these decidualized arteries can be observed by Days 18-20 (P1. 1, Fig. 4).

Our observations lend support to the idea that decidualized cells have a limited life-span and that progesterone "acts in a permissive rather than in a directive manner" (Finn \& Martin, 1974). The co-existence of immature deciduomata with mature deciduomata showing necrosis in animals given the same daily dose of progesterone indicates that fluctuations in the peripheral plasma progesterone level play no part in determining the onset of necrosis in the spiral arteries. On the other hand, we have been struck by the relationship of stromal granulocytes to decidual necrosis. During decidualization, granulocytes appear first in the spiral segments and 3-4 days later in the medial terminal segments. The onset of necrosis in the two parts of the same artery is separated by a similar time interval, and only occurs in the medial terminal arteries when pregnancy is artificially prolonged. These observations suggest that stromal granulocytes, probably by a lysosomal action (Pijnenborg, 1975), may play an important role in decidual necrosis.

This work has been supported by Grant 20,035 from the Fonds voor Geneeskundig Wetenschappelijk Onderzoek of the Belgian Government.

\section{References}

Finn, C.A. \& MarTin, L. (1974) The control of implantation. J. Reprod. Fert. 39, 195-206.

FinN, C.A. \& Pollard, R.M. (1973) Influence of the oestrogen secreted before oestrus on the timing of endometrial sensitivity and insensitivity during implantation. J. Endocr. 56, 619-620. 

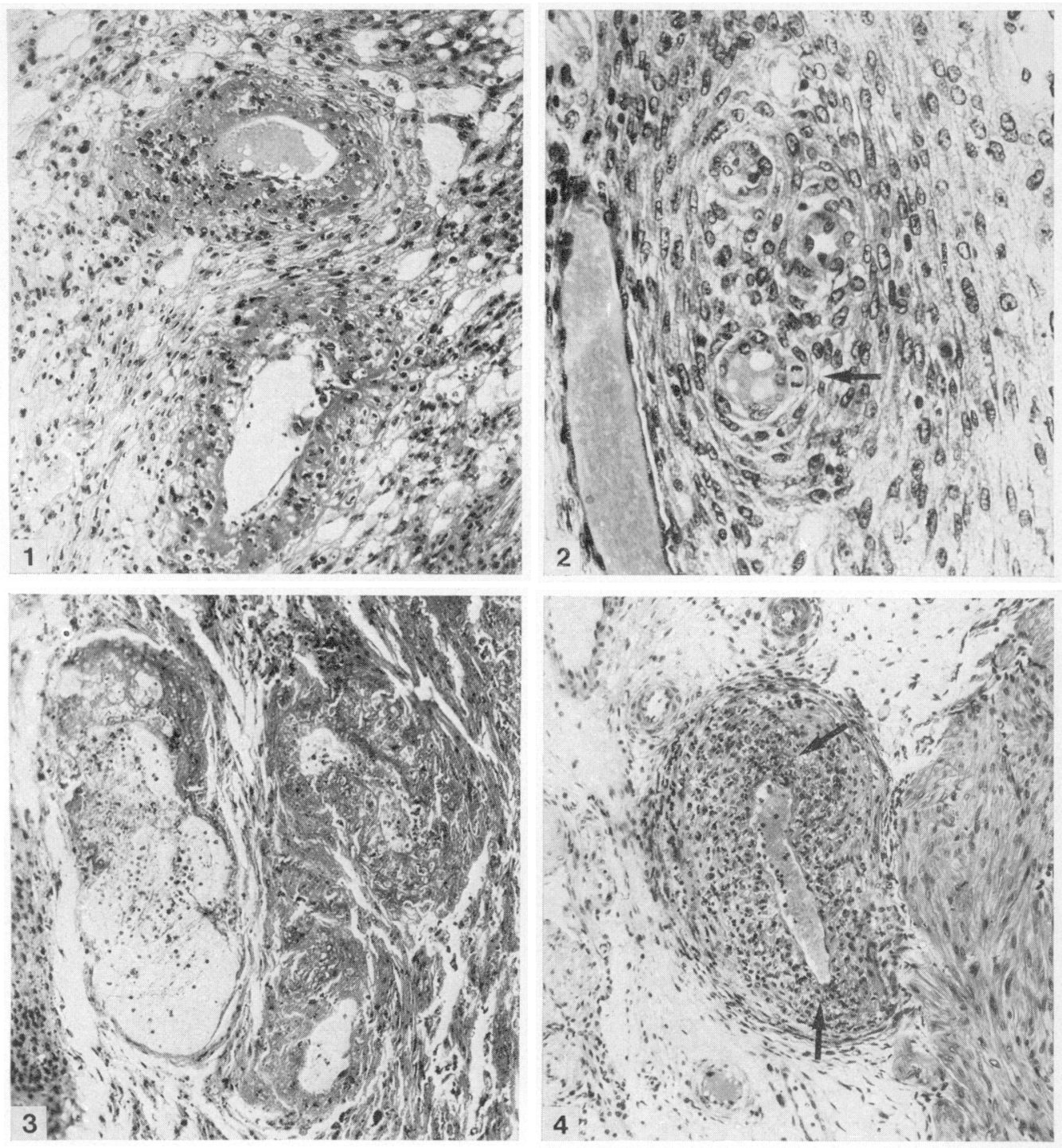

All tissues, stained with haemalum and $\operatorname{cosin}$, were obtained at autopsy from pseudopregnant golden hamsters. The mesometrial side is on the left.

Fig. 1. Artificially prolonged pseudopregnancy at Day 18. There is necrosis of the vessel wall of a central spiral artery of a deciduoma corresponding to Day $18 . \times 100$.

Fig. 2. Central spiral artery of a Day 7 or 8 deciduoma, obtained from the same Day 18 pseudopregnant animal as the specimen of Fig. 1, showing proliferation (mitotic figure, arrow) and early swelling of the cells in the wall. $\times 250$.

Fig. 3. Central spiral artery of a Day 20 deciduoma showing necrosis of the vessel walls and the surrounding tissues. $\times 100$.

Fig. 4. Medial terminal artery of a Day 18 deciduoma in which necrosis has begun as shown by the fragmentation of nuclei (arrows). $\times 100$. 
Gutknecht, G.D., Wyngarden, L.J. \& PharRiss, B.B. (1971) The effect of prostaglandin $F_{2 \varepsilon}$ on ovarian and plasma progesterone levels in the pregnant hamster. Proc. Soc. exp. Biol. Med. 136, 1151-1157.

Lukaszewska, J.H. \& Greenwald, G.S. (1970) Progesterone levels in the cyclic and pregnant hamster. Endocrinology 86, 1-9.

Orsin, M.W. (1968) Observations on deciduomata in sterile horns of pregnant hamsters. J. Endocr. 41, vii.

Pisnenborg, R., Robertson, W.B. \& Brosens, I. (1974) The arterial migration of trophoblast in the uterus of the golden hamster, Mesocricetus auratus. J. Reprod. Fert. 40, 269-280.

Pinngngorg, R., Robertson, W.B. \& Brosens, I. (1975) The role of ovarian steroids in placental development and endovascular trophoblast migration in the golden hamster. J. Reprod. Fert. 44, 43-51.

PiJnengorg, R. (1975) Placentation in the golden hamster (Mesocricetus auratus Waterhouse). Doctoraatsthesis, Acco, Leuven.

TuRNBUlL, J.G. \& KeNT, G.C. (1963) The decidual cell response in the golden hamster. Anat. Rec. 145, 97-99.

Received 7 June 1976 